延特有の異方性の問題等むあるが，使用条件にあわせた 最適条件を選定することにより種々の特性を有す鋼板を 作り分けることも可能であり今後の発展が期待される.

本報が制御圧延鋼の理解に少しであ役立てばと思いて の拙文をまとめた．御参考になれば幸いである.

\section{文献}

1）鉄之鋼「非調質高張力鋼特集号」，58-13(昭 47-11).

2）柴田浩司，鉄と鋼，67-7 (昭 56-6), p. 1026.

3）大森靖也, 日本金属学会報, 30-12 (昭 41), p. 1164 .

4）長谷部茂夫, 鉄鋼界, 22-4 (昭 47), p. 37.

5）松原博義・大須賀立美・小指軍夫ほ力，鉄之鋼， 58-13 (昭 47), p. 1848.

6）福田 実・橋本 保，国重和俊，ibid， p. 1832.

7）関根 寛 - 丸山忠克, 製鉄研究, 289 (昭 51), p. 11920 .

8）池島俊雄，鉄と鋼，65-10 (昭 54)，p. 1644 .

9）福田実・橋本保・鈴木 改任加, 住友金属, 30-1
（昭 48）, p. 78 .

10）田中智夫, 日本金属学会報, 17-2（昭 48), p. 104 .

11）大谷泰夫・橋本 保, 熱処理, 20-3 (昭 55-4), p. 136.

12）田中智夫 - 波戸村太根生・田畑綽久，川崎製鉄技報，6 -4 (昭 49), p. 522 .

13）束田幸四郎・ほか，鉄と鋼，67-4（昭 56-3）， p. '81 $\mathrm{S} 340$.

14）有方和義・松本和明・山崎喜岸・ほ加, 鉄と鋼, 67-13 (昭 56), p. S 1329 1332.

15）尾上泰光·森川博文 - 十河泰雄 · ほ加, ibid, p. S $1334 \sim 1336$.

16）橋本 保, 鈴木秀一・ほか, ibid, p. S $1323,1327$.

17）伊藤慶典・別所 清, 鉄と鋼, 58-13 (昭 47), p. 1812 .

18）日本圧力容器研究会議 (JPVRC) 材料部会調査報告 $\lceil\mathrm{CR}$ 鋼板のタンク, 圧力容器への適用について」昭和 56 年 4 月.

19）住友金属工業(株)データ・シート, P. DS 11 「SHT低 温用鋼板の疲労特性について」.

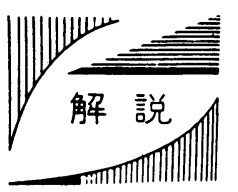

\title{
クラッド 鋼*
}

円尾俊明 ${ }^{* *}$. 島崎正英 ${ }^{* *}$

\section{1.はじめに}

近年における各種産業の著しい発展は, 材料の使用環 境をますます厳しいものとし，材料に対する機械的性質 および耐食性，耐久性の要求は非常に加酷なものとなっ てきた，それと同時に，コス卜低减，資源節約に対する 要求も厳しく，てれに応える材料としてクラッド鋼が注 目され広く用いられるようになってきている。

クラッド鋼 (Clad Steel) とは, 軟鋼あるいは低合金 鋼などの鋼材を他の金属で全面にわたり冶金的に被覆し たもので, 安価で且つ機械的性質に優れる鋼材 (以下母 材という) と耐食耐久性に優れる被覆金属(以下合せ材之 いう)の特徵を生かした複合材料の一種である. 合せ材 の種類によってステンレスクラッド鋼, ニッケルおよび ニッケル合金クラッド鋼，銅および銅合金クラッド鋼あ るいはチタンクラッド鋼などと呼ばれており, 各種化学 装置, ケミカルタンカー, 海水淡水化装置などに広く用 いられている.

本稿では, クラッド鋼の製造法, 規格, 性能例, 加工 ならびに溶接などについて概説したい。

\footnotetext{
* 原稿受付 昭和 56 年 11 月 24 日

**（株）日本製鋼所室欄製作所（室欄市茶津町 4 番地）
}

\section{2. クラッド鋼に関する規格}

クラッド鋼に関する規格は, 1943 年ASTMにより制 定されて以来多くの国家あるいは団体規格が制定されて きている. わが国においては，日本高圧力技術協会規格 労働省規定などがあったが，1977〜1980 年にかけて日 本高圧力技術協会クラッド研究委員会により整備および 原案が作成され，JIS規格が制定された。

表 1 はクラッドに関する主要規格の概要を示したあの で, 接合 (せん断) 強さに対する要求值は JIS 規格が最む 厳しいものとなっている。また，JIS規格では世界に先 駆けてチタンクラッド鋼が制定された外，合せ材の種類 によって製造法が規定されているのが特徴である.

その他, ステンレスクラッド鋼については加工規準な らびに溶接施工確認試験方法が，それぞれ日本高圧力技 術協会規格 HPIS-E-105，106亿制定されている.

\section{3. クラッド鋼の製造法}

金属を治金的に接合させるには，相互に原子間引力の 働く距離にまで近づけてやるととが必要であり，てれを 達成するためには, 高温, 高圧力あるいは両者の組合せ が必要となる.

クラッド鋼の製造については, 従来数多くの特許が出 


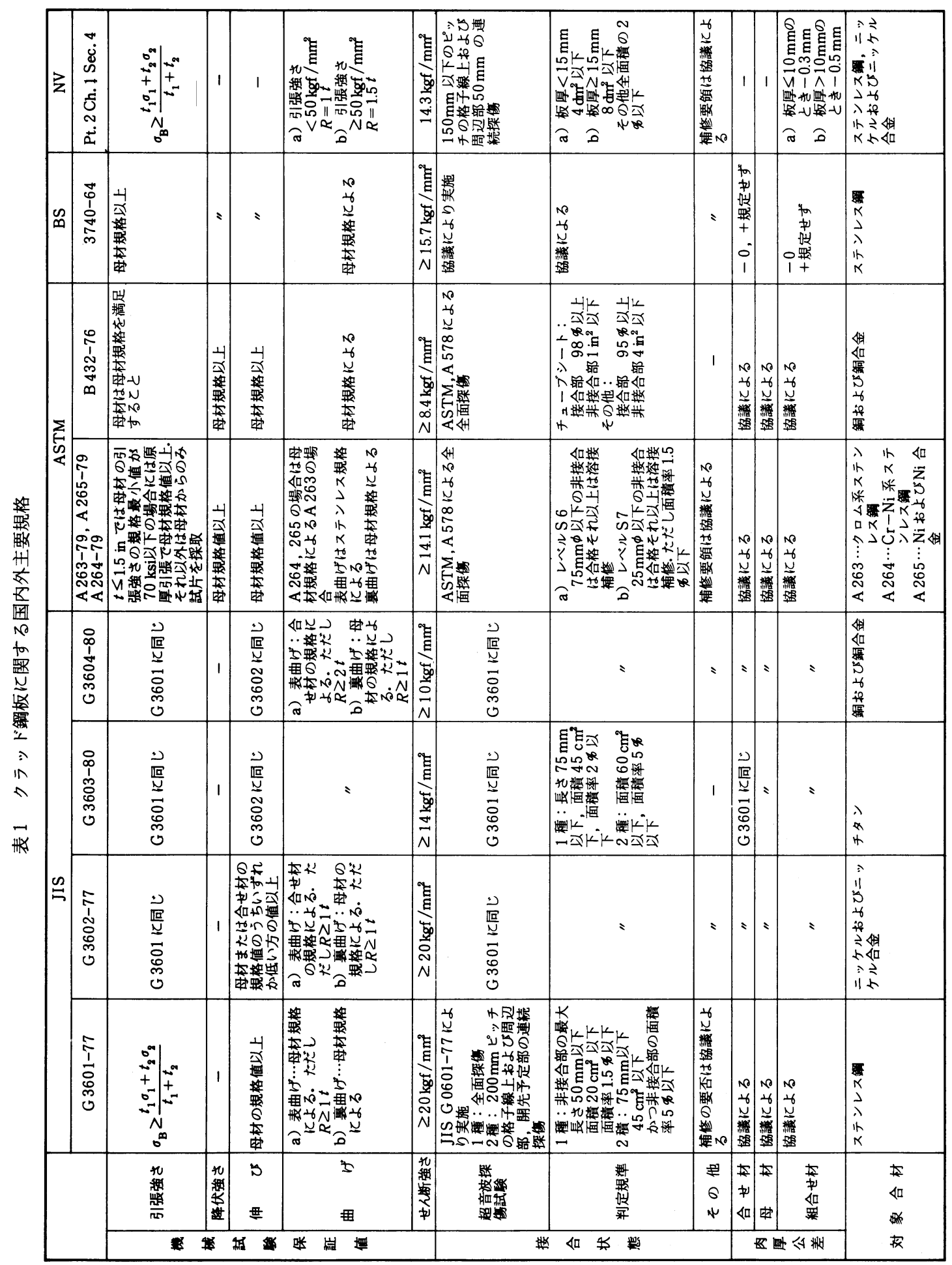


願されているが, 現在主として工業的に行われているの は, 圧延珐着法, 爆着法, 爆着圧延法, 肉盛法, 肉盛圧 延法ならびに鋳包み圧延法である. その他最近，ブレー ジングにより組合せ素材を接合させた後てれを圧延する 方法や，従来比較的小物部材にしか使用されていなかっ た拡散接合法を，管板など大型部材へ適用する方法が報 告されている1).

（1）圧延クラッド鋼压延圧着法には冷間圧延法と 熱間圧延法があるが，極薄板を除いては通常熱間圧延法 により製造されている．接合面を機械的あるいは化学的 に研摩された合せ材および母材は，図 1 に示すようなサ ンドイッチに組合された後，加熱・圧延により治金的に 接合される.との時接合面には，接合を容易にしまた接 合界面における有害な合金層の形成あるいは母材から合 材への浸炭を防止するためニッケルなどのめっきが施さ れるのが普通である ${ }^{2)}$.

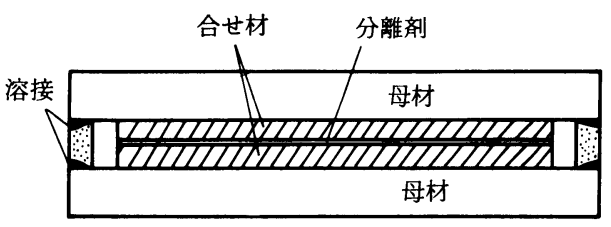

図 1 圧延クラッド鋼の製造方法

圧延クラッド鋼は，大面積の板の製造が容易で溶接線 を减ずることができるとか，高温において接合界面での 炭素移動が少ないなどの長所があるが，母材に対し著し く融点が低い金属とか他の金属之金属間化合物を作り易 い合金を合せ材とするクラッド鋼の製造が難しいなどの 欠点を有している。また，製造最大板厚は全厚でほぼ $150 \mathrm{~mm}$ 程度である.

各種オーステナイト系, フェライト系, マルテンサイ ト系および二相ステンレスクラッド鋼の外，ニッケル， モネル,インコネル, インコロイ, 銅, キュプロニッケ ル，ネーバル黄鋼，アルミ青銅などのクラッド鋼が製造 されている。

（2）爆着ならびに爆着圧延クラッド鋼 図 2 に示し たように爆薬の爆発により高圧力を得，合せ材を母材に 衝突させて接合を行う. 前処理工程で接合面は研摩され るが, 更に残留する酸化層や窒化層などは爆着時, 金属 ジェットにより除去され接合が行われる. 合せ材および 母材は瞬間的に流体化するため, 接合界面がさざ波状を 呈するのが特徴である.

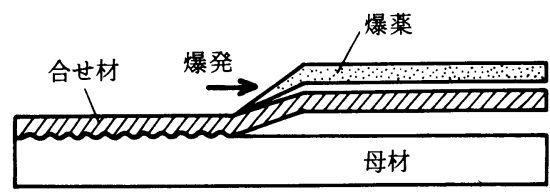

困 2 爆着クラッド鋼の製造法
爆着クラッド鋼は瞬時にして接合が完了するため, 接 合界面における有害合金層の形成がほとんどないとか, 融点の相当異なる金属のクラッド化が容易であるとか， 円筒，ノズルなど板以外の形状にも適用できるなどの長 所を有している. しかし，その爆発音のため製造場所が 限られるとともに比較的小物の製造に限られるとか, 高 強度材料への適用が難しいなどの欠点がある ${ }^{3)}$.

製造品種は，圧延クラッド鋼で述べたほか，アルミニ ウム, チタンおよび貴金属を合せ材とするクラッド鋼な どである. 製造最大面積は $21 \mathrm{~m}^{2}$ 程度であるが, 爆着後 圧延するととにより大面積あるいは薄物の製造が可能で ある.とのようにして製造されたクラッド鋼を爆着圧延 クラッド鋼と言う.

（3）肉盛ならびに肉盛圧延クラッド鋼帯状電極エ レクトロスラグ溶接, サブマージアーク溶接あるいは逆 極性プラズマアーク溶接などの各種溶接法により，母材 上に直接肉盛溶接してクラッド鋼を得る方法で, 素材と してよりはむしろ溶接施工の一つとして適用されている.

母材の成形加工後クラッド化することができ，極厚物 あるいはノズル，フランジなど容易にクラッド化できる が, 溶接材料, 溶接施工法ならびに溶接後熱処理などの 管理には十分配慮する必要がある4). オーステナイト系 ステンレス鋼, マルテンサイト系ステンレス鋼およびイ ンコネルが主として用いられている.

肉盛後圧延を行いクラッド鋼を製造する方法が肉盛圧 延法である. ステンレスクラッド鋼が主として製造され， 最小合せ材厚さ $50 \mu$, 全厚 $0.8 \mathrm{~mm}$ までの極薄物が製造 されている1).

（4）鋳包み压延クラッド鋼 スカムの巻込みを防ぐ ため接合面に特殊な処理を施した合せ材を図 3 に示した ように鋳型内に吊しておき，母材を鋳込みクラッド鋳塊 を製造した後圧延して製造したクラッド鋼である．大量 生産に適しているが，母材より融点の低い金属のクラッ ド化は困難である．表面硬化軟鋼之か表面軟化高張力鋼 の製造法として注目されている1).

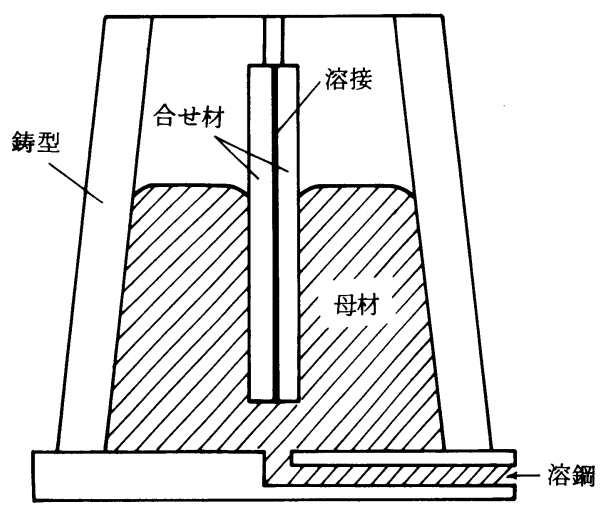

困 3 鋳包みクラッド鋼の製造法

February, 1982 


\section{4. クラッド鋼の性能}

4.1 クラッド鋼の諸特性式 クラッド鋼の機械 的および物理的性質は，接合界面における拡散層の存在 を無視すれば表 2 亿示す諸式で与えられる 質については, クラッド鋼の端面が腐食環境にさらされ る場合, 電気化学的腐食の問題があり十分注意する必要 がある.

4.2 クラッド鋼の機械的性罂各種製造法によ り製造されたクラッド鋼の機械的性質例を表 3 表 7 に 示した ${ }^{1}$. いずれも規格を十分に満足するものである.

図 4 は市販の圧延, 爆着ならびに肉盛クラッド鋼につ いて, 日本高王力技術協会クラッド研究委員会により実 施された研究のうち， $316 \mathrm{~L}$ ステンレスクラッド鋼の引 張，せん断，はく離ならびに疲れ試験結果を示したもの である ${ }^{6}$ ．良好な性能を示しており，冷間あるいは熱間 加工によっても接合強さの劣化は認められていない．圧
表 2 クラッド鋼板の複合特性式

\begin{tabular}{|c|c|}
\hline 引張強さ $\sigma_{\mathbf{B}}\left(\mathrm{kg} / \mathrm{mm}^{2}\right)$ & 弾性係数 $E\left(\mathrm{~kg} / \mathrm{mm}^{2}\right)$ \\
\hline$\sigma_{\mathrm{B}}=\frac{t_{1} \sigma_{\mathrm{B} 1}+t_{2} \sigma_{\mathrm{B} 2}}{t_{1}+t_{2}}$ & $E=\frac{t_{1} E_{1}+t_{2} E_{2}}{t_{1}+t_{2}}$ \\
\hline 熱伝導度 $K\left(\mathrm{cal} / \mathrm{sec} /{ }^{\circ} \mathrm{C} / \mathrm{cm}\right)$ & 熱膨張係数 $\alpha(\mathrm{C})$ \\
\hline $\begin{array}{l}\text { (1) 表面に垂直方向 } \\
\frac{100}{K}=\frac{a_{1}}{K_{1}}+\frac{a_{2}}{K_{2}} \\
\text { (2) 表面に平行方向 } \\
100 K=a_{1} K_{1}+a_{2} K_{2}\end{array}$ & $\begin{array}{l}\text { (1) 厚さ方向 } \\
100 \alpha=a_{1} \alpha_{1}+a_{2} \alpha_{2} \\
\text { (2) 長さ方向 } \\
\alpha=\alpha_{1}+\frac{\left(\alpha_{2}-\alpha_{1}\right) t_{2} E_{2}}{t_{2} E_{2}+t_{1} E_{1}}\end{array}$ \\
\hline \multicolumn{2}{|c|}{ 曲率半径 $\rho(\mathrm{mm})$} \\
\hline \multicolumn{2}{|c|}{$1=\frac{6\left(t_{1}-t_{2}\right)\left(\alpha_{2}-\alpha_{1}\right)(\Delta T)}{=}$} \\
\hline \multicolumn{2}{|c|}{$\overline{\left(E_{1} t_{1}^{3}+E_{2} t_{2}^{3}\right)\left(\frac{1}{E_{1} t_{1}}+\frac{1}{E_{2} t_{2}}\right)+3\left(t_{1}+t_{2}\right)^{2}}$} \\
\hline
\end{tabular}

$t$ : 各構成材の厚さ $(\mathrm{mm})$

$a$ : 各構成材の厚さ比 (\%)

$\Delta T:$ 温度変化 $\left({ }^{\circ} \mathrm{C}\right)$

添字 1 は母材, 添字 2 は合せ材の値を示す.

表 3 圧延クラッド鋼の機械的性質例

\begin{tabular}{|c|c|c|c|c|c|c|c|c|}
\hline \multirow{2}{*}{ 合 女 材 } & \multirow{2}{*}{ 母 材 } & \multirow{2}{*}{$\begin{array}{l}\text { 板厚 } \\
(\mathrm{mm})\end{array}$} & \multicolumn{3}{|c|}{ 引張 試 験 } & \multicolumn{2}{|c|}{$\begin{array}{l}\text { 曲げ試験 } \\
(R=1.0 t)\end{array}$} & \multirow[b]{2}{*}{$\begin{array}{c}\text { せん断強さ } \\
\left(\mathrm{kgf} / \mathrm{mm}^{2}\right)\end{array}$} \\
\hline & & & $\begin{array}{c}\text { 降伏強さ } \\
\left(\mathrm{kgf} / \mathrm{mm}^{2}\right)\end{array}$ & $\begin{array}{c}\text { 引張強さ } \\
\left(\mathrm{kgf} / \mathrm{mm}^{2}\right)\end{array}$ & $\begin{array}{l}\text { 伸 び } \\
\text { (क) }\end{array}$ & 表曲げ & 裏曲げ & \\
\hline TP $316 \mathrm{~L}$ & API 5 LX X60 & $2+12$ & 46.3 & 60.5 & 25.3 & 良好 & 良好 & $29.3,30.5$ \\
\hline TP $329 \mathrm{~J} 1$ & SM41 B & $3+44$ & 29.6 & 45.2 & $35.0 \%$ & " & " & $32.9,33.3$ \\
\hline TP 405 & SB 42 & $3+20$ & 30.5 & 48.5 & 29.5 & $"$ & $"$ & $30.5,32.1$ \\
\hline TP 444 & SB 42 & $3+11$ & 33.0 & 45.1 & 25.7 & $" 1$ & $"$ & $31.7,34.6$ \\
\hline インコロイ 825 & A 516 Gr. 60 & $3+18$ & 32.5 & 50.2 & $46.0 \%$ & " & " & $31.2,34.9$ \\
\hline インコネル 625 & SM41C & $4+9$ & - & 59.4 & $48.8^{*}$ & $"$ & $"$ & $36.1,39.1$ \\
\hline モネル & SB 42 & $6+86$ & 36.3 & 53.4 & 28.2 & " & " & $32.4,32.9$ \\
\hline 銅 & DIN $17155 \mathrm{H} 2$ & $3.5+19$ & 30.3 & 40.6 & 28.5 & " & " & $14.3,13.9$ \\
\hline $90 / 10$ キュプロニッケル & SS 41 & $3+20$ & 29.8 & 46.4 & 32.3 & "I & "I & $21.5,22.3$ \\
\hline アルミ青銅 & SB 42 & $3+19$ & 34.6 & 50.2 & 23.9 & $"$ & " & $22.8,23.5$ \\
\hline 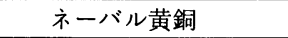 & SS 41 & $10+80$ & 32.2 & 49.6 & 30.8 & " & " & $20.0,21.3$ \\
\hline $90 / 10$ キュプロニッケル & TP $316 \mathrm{~L}$ & $3+7$ & 16.5 & 45.5 & $46.7^{\star}$ & " & $"$ & $18.7,19.5$ \\
\hline
\end{tabular}

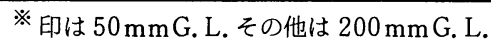

表 4 爆着クラッド鋼の機械的性質例

\begin{tabular}{|c|c|c|c|c|c|c|c|c|c|}
\hline \multirow[b]{2}{*}{ 合 } & & \multirow[b]{2}{*}{ 母 材 } & \multirow{2}{*}{$\begin{array}{l}\text { 板厚 } \\
(\mathrm{mm})\end{array}$} & \multicolumn{3}{|c|}{ 引 張 試 験 } & \multicolumn{2}{|c|}{ 曲げ試験 $(R=t)$} & \multirow{2}{*}{$\begin{array}{l}\text { せん断試験 } \\
\left(\mathrm{kgf} / \mathrm{mm}^{2}\right)\end{array}$} \\
\hline & & & & $\begin{array}{c}\text { 降伏強さ } \\
\left(\mathrm{kgf} / \mathrm{mm}^{2}\right)\end{array}$ & $\begin{array}{c}\text { 引張強さ } \\
\left(\mathrm{kgf} / \mathrm{mm}^{2}\right)\end{array}$ & $\begin{array}{c}\text { 伸 び } \\
\text { (\%) }\end{array}$ & 表曲げ & 裏曲げ & \\
\hline \multicolumn{2}{|c|}{ 銅 } & S S 41 & $2+14$ & 28.3 & 41.2 & 29.3 & 良好 & 良好 & $18 \sim 20$ \\
\hline \multicolumn{2}{|c|}{ リン青銅 } & S S 41 & $2+8$ & 30.3 & 46.6 & 32.2 & 11 & 1 & $27 \sim 33$ \\
\hline \multicolumn{2}{|c|}{ ネーバル } & S B 42 B & $2+12$ & 30.4 & 47.7 & 31.4 & " & " & $22 \sim 25$ \\
\hline \multicolumn{2}{|c|}{ アルミ青銅 } & TP 304 & $10+40$ & - & 61.3 & 30.5 & $"$ & " & $33 \sim 33$ \\
\hline \multicolumn{2}{|c|}{ ハステロイB } & S B 42 B & $2+12$ & 32.1 & 51.2 & 36.4 & " & " & $30 \sim 37$ \\
\hline \multicolumn{2}{|c|}{ ハステロイC } & S S 41 & $2+12$ & 31.4 & 50.8 & 36.0 & " & " & $42 \sim 45$ \\
\hline \multicolumn{2}{|c|}{ TP 304} & S S 41 & $6+25$ & 37.0 & 51.3 & 40.0 & " & " & $35 \sim 40$ \\
\hline \multicolumn{2}{|c|}{ アルミニウム } & S S 41 & $2+10$ & 24.1 & 39.6 & 33.0 & $"$ & " & $6 \sim 10$ \\
\hline \multicolumn{2}{|c|}{ チタン } & S B 42 B & $2+9$ & 35.1 & 48.7 & 32.0 & " & " & $34 \sim 42$ \\
\hline \multicolumn{2}{|c|}{ チタン } & T P 304 & $2+11$ & - & 61.5 & 54.3 & " & " & $36 \sim 40$ \\
\hline \multicolumn{2}{|c|}{ プラチナ } & $\mathrm{Ti}$ & $5 \mu+1$ & - & 41.3 & 38.5 & $\prime \prime$ & " & - \\
\hline
\end{tabular}


表 5 鋳ぐるみクラッド鋼の機械的性質例

\begin{tabular}{|c|c|c|c|c|c|c|c|}
\hline \multirow[b]{2}{*}{ 合 せ 材 } & \multirow[b]{2}{*}{ 母 材 } & \multirow[b]{2}{*}{ 板厚 $(\mathrm{mm})$} & \multicolumn{3}{|c|}{ 引 張 試 験 } & \multicolumn{2}{|c|}{ 曲 げ試 験 } \\
\hline & & & $\begin{array}{c}\text { 降伏強さ } \\
\left(\mathrm{kgf} / \mathrm{mm}^{2}\right)\end{array}$ & $\begin{array}{c}\text { 引張強さ } \\
\left(\mathrm{kgf} / \mathrm{mm}^{2}\right)\end{array}$ & $\begin{array}{l}\text { 伸び } \\
\text { (\%) }\end{array}$ & $\begin{array}{c}\text { 表曲げ } \\
(R=t)\end{array}$ & $\begin{array}{l}\text { 側曲げ } \\
(R=t)\end{array}$ \\
\hline 低炭素アルミキルド & SPV $50 \mathrm{Q}$ & 38 & 53.2 & 63.2 & 23 & 良好 & $\begin{array}{c}\text { 良好 } \\
(R=0.5 t)\end{array}$ \\
\hline TP 304 & SM 50 A & 18 & 43.7 & 58.5 & 29 & $"$ & 良好 \\
\hline TP 410 & SM 50A & 18 & 38.3 & 54.0 & 28 & " & " \\
\hline
\end{tabular}

表 6 ブレージング圧延クラッド鋼の機械的性質例

\begin{tabular}{|c|c|c|c|c|c|c|c|}
\hline & \multirow[b]{2}{*}{ 母 材 } & \multirow[b]{2}{*}{ 板厚 $(\mathrm{mm})$} & \multicolumn{2}{|c|}{ 引張 試 験 } & \multicolumn{2}{|c|}{ 曲 げ 試 験 } & \multirow{2}{*}{$\begin{array}{l}\text { せん断強さ } \\
\left(\mathrm{kgf} / \mathrm{mm}^{2}\right)\end{array}$} \\
\hline 材 & & & $\begin{array}{c}\text { 引張強さ } \\
\left(\mathrm{kgf} / \mathrm{mm}^{2}\right)\end{array}$ & $\begin{array}{l}\text { 伸び } \\
\text { (\%) }\end{array}$ & $\begin{array}{c}\text { 表曲げ } \\
(R=2.0 t)\end{array}$ & $\begin{array}{c}\text { 裏曲げ } \\
(R=1.5 t)\end{array}$ & \\
\hline \multirow{2}{*}{$90 / 10$ キュプロニッケル } & SS 41 & $3.0+11.0$ & $\begin{array}{c}45.7 \\
(38.2)^{1)}\end{array}$ & $\begin{array}{c}23.6 \\
(17.0)^{1)}\end{array}$ & 良好 & 良好 & $\begin{array}{c}20.8,21.3,21.7 \\
(10)^{1)}\end{array}$ \\
\hline & SB 46 & $2.8+11.2$ & $\begin{array}{c}48.3 \\
(42.4)^{1)}\end{array}$ & $\begin{array}{c}24.1 \\
(19.0)^{1)}\end{array}$ & $"$ & " & $\begin{array}{c}21.6,22.0,3^{21.2} \\
(10)^{1}\end{array}$ \\
\hline
\end{tabular}

1) JIS G 3604 による下限規格值

表 7 拡散溶接クラッド鋼.の機械的性質例

\begin{tabular}{|c|c|c|c|c|c|c|c|}
\hline \multirow[b]{2}{*}{ 合 せ 材 } & \multirow[b]{2}{*}{ 母 材 } & \multirow[b]{2}{*}{ 板厚 $(\mathrm{mm})$} & \multicolumn{2}{|c|}{ 引 張 試 験 } & \multicolumn{2}{|c|}{ 曲げ試 験 } & \multirow{2}{*}{$\begin{array}{l}\text { せん断強さ } \\
\left(\mathrm{kgf} / \mathrm{mm}^{2}\right)\end{array}$} \\
\hline & & & $\begin{array}{c}\text { 引張強さ } \\
\left(\mathrm{kgf} / \mathrm{mm}^{2}\right)\end{array}$ & $\begin{array}{l}\text { 伸び } \\
(\%)\end{array}$ & $\begin{array}{c}\text { 表曲げ } \\
(R=1.0 t)\end{array}$ & $\begin{array}{c}\text { 裏曲げ } \\
(R=1.0 t) \\
\end{array}$ & \\
\hline $90 / 10$ キュプロニッケル & SM $50 \mathrm{~B}$ & $10+75$ & 51.2 & 31.0 & $\begin{array}{c}\text { 良好 } \\
(R=2.0 t)\end{array}$ & $\begin{array}{c}\text { 良好 } \\
(R=1.5 t)\end{array}$ & $20 \sim 23$ \\
\hline $70 / 30$ 黄銅 & SS 41 & $4.5+21$ & 41.5 & 37.5 & $"$ & $" 1$ & $18 \sim 22$ \\
\hline TP $316 \mathrm{~L}$ & SM 41 B & $10+52$ & 48.3 & 38.5 & 良好 & 良好 & $29 \sim 33$ \\
\hline ハステロイC & SM 41B & $3+52$ & 50.4 & 39.5 & $\prime \prime$ & $" 1$ & $35 \sim 38$ \\
\hline \multirow{2}{*}{$\begin{array}{l}90 / 10 \text { キュプロニッケル } \\
\text { - TP 316 L }\end{array}$} & \multirow{2}{*}{ SM 41B } & \multirow{2}{*}{$10+52+10$} & 46.4 & 33.5 & $\begin{array}{c}\text { 良好 } \\
(R=2.0 t) \\
\end{array}$ & " & $20 \sim 23$ \\
\hline & & & 48.1 & 38.0 & 良好 & $\prime \prime$ & $29 \sim 33$ \\
\hline
\end{tabular}

延クラッド鋼と爆着クラッド鋼の機械的性質の若干の差 は，主として爆着による接合界面の加工硬化によるもの と考えられている.

図 5 は圧延法により製造された各種銅合金クラッド鋼 ならびにモネルクラッド鋼の熱処理による接合強さの変 化を示したものである7). ラルソン・ミラーパラメータ で 22 以下の加熱による劣化は全く認められないが， ネーバル黄銅クラッド鋼では 23 以上で低下するように

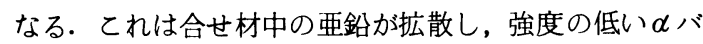
ンドが形成されると同時に拡散孔が生成されるためで, 高温・長時間の加熱は好ましくない.

オーステナイト系ステンレスクラッド鋼のように，熱 膨張係数の相当異なるクラッド鋼が熱サイクルを受けた 場合, 冷却時合せ材はかなりの引張応力を受け表面より 割れが発生したとの報告がある ${ }^{8)}$. しかしてれは, 表面 に切欠があったためで, 接合界面でのクラックの発生お よび進展は認められていない. 表 8 は圧延 $316 \mathrm{~L}$ ステン レスクラッド鋼板の連続熱サイクルによるせん断強さの 変化を示したもので, 3500 回の熱サイクルによっても劣 化は認められない ${ }^{9)}$.

\section{3 クラッド鋼の耐食性 クラッド鋼はその製} 造法の特徴や熱的取扱い条件などを十分考慮して製造さ れるため, 合せ材の耐食性はその単体と同等の性能を示 すと思ってよい.

表 9〜表 11 に圧延クラッド 鋼板に関する各種腐食試 験結果を示した ${ }^{10)}$. クラッド鋼合せ材はその単体と同等 の耐食性を示しており，またクラッド鋼の継手も十分な 耐食性を有していることが分る.

\section{5. クラッド鋼の加エならびに溶接}

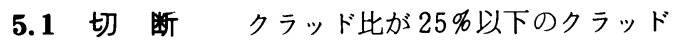
鋼は, 通常のガス切断機により容易に切断することがで きる. この時, 切断は母材側より行い, トーチは後方に 約 $15^{\circ}$ 傾けると良い. また, 軟鋼の切断と比較して火口 径は若干大きめに, 酸素圧は若干低目が良いといわれて いる. 標準切断条件を表 12 に示した ${ }^{11)}$. クラッド比が $30 \%$ 超える場合はパウダー切断が用いられるが，乙 の時は合せ材側より行う.

プラズマ切断は切断肌が良好であり，非鉄クラッド鋼 の切断に多く用いられている. 切断条件は軟鋼と同じで 


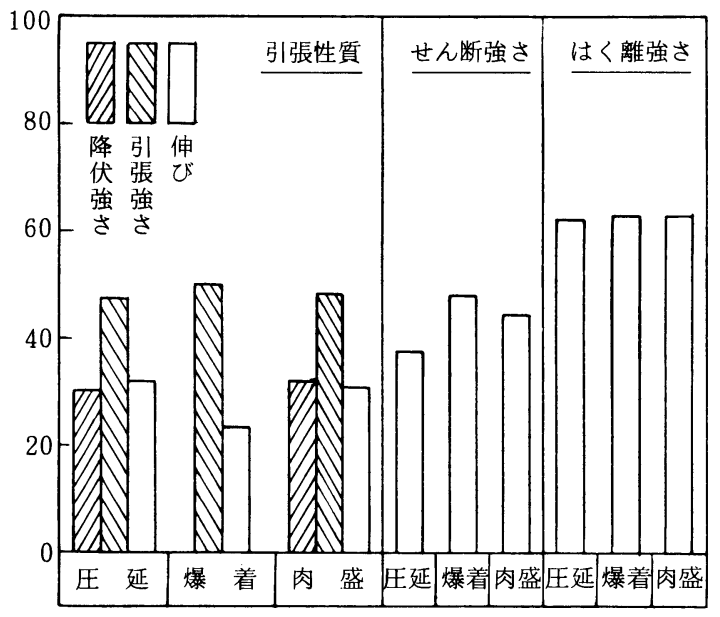

（a）各種クラッド鋼の機械的性質

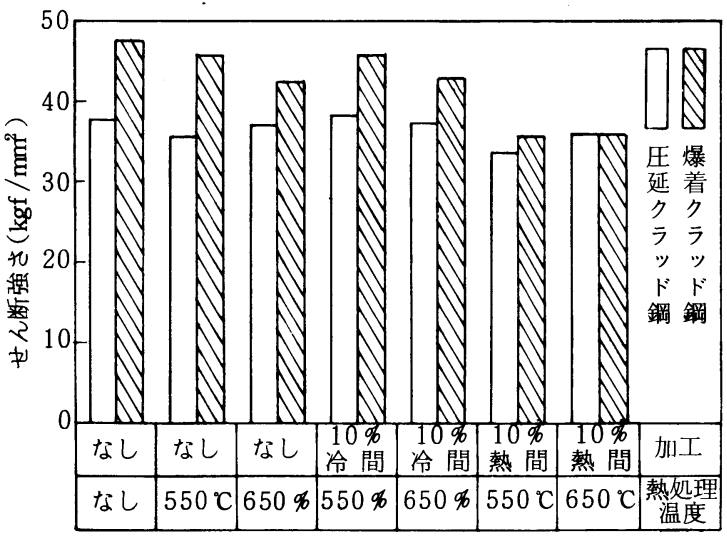

（b）加工および熱処理によるせん断強さの変化

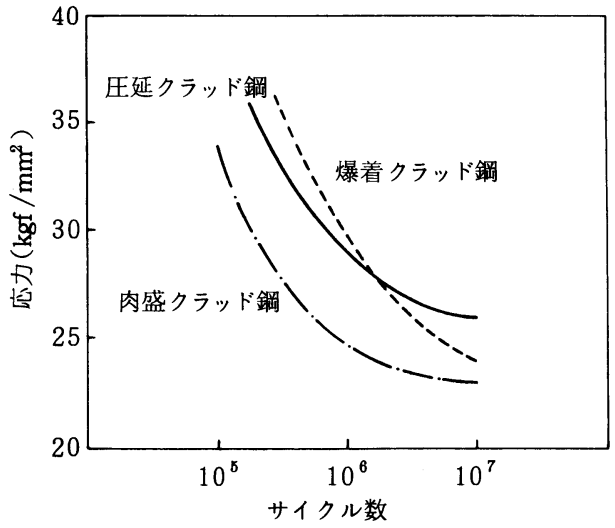

(c) 接合界面の疲れ試験結果

困 4 各種クラッド鋼の機械的性質
良いが，合せ材側より切断を行う.なお，比較的薄物 (12 mm 程度まで)についてはシャーリングあ可能であ るが、合せ材側より作業を行う必要がある.

5.2 成 形 クラッド鋼の成形加工は通常の鋼材 同様，ロール曲げ，プレス加工あるいはスピニング加工 などにより行われる．合せ材の特性を生かすためには冷 間加工によるのが良いが，板厚とか母材強度によっては 温間あるいは熱間加工が行われる. 耐食性などの劣化を

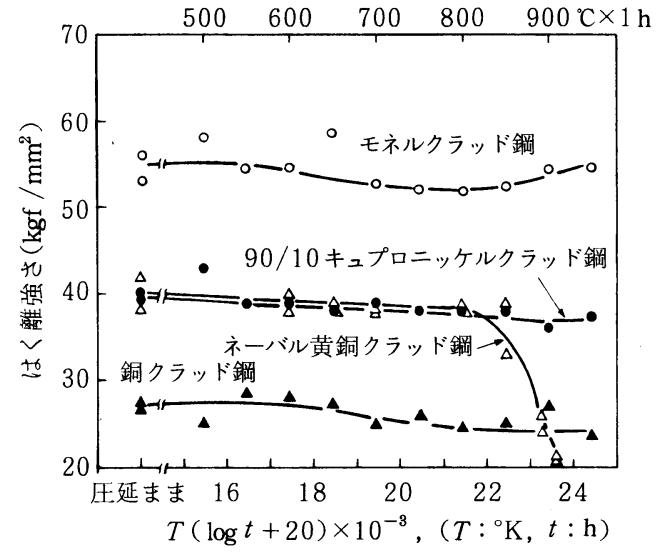

困 5 熱処理による銅合金およびモネルクラッド鋼の 接合強さの変化(圧延クラッド鋼)

表 8 連続熱サイクルによる $316 \mathrm{~L}$ ステンレス クラッド鋼のせん断強さの変化 (圧延ク ラッド鋼, $3+25 t$ )

\begin{tabular}{|c|c|c|}
\hline \multirow{2}{*}{ 熱サイクル1) } & \multicolumn{2}{|c|}{ せん断強さ $\left(\mathrm{kgf} / \mathrm{mm}^{2}\right)$} \\
\cline { 2 - 3 } & 熱サイクル付加前 & 熱サイクル付加後 $\left.{ }^{2}\right)$ \\
\hline $50-100^{\circ} \mathrm{C}$ & 30.0 & $30.1,32.3,34.0$ \\
\cline { 1 - 1 } $150-400{ }^{\circ} \mathrm{C}$ & 34.7 & $31.1,31.5,32.8$ \\
\hline 1) 1 サイクル: 1 分 30 秒, ${ }^{2)} 3500$ 回
\end{tabular}

表 9 ステンレスおよびニッケル合金クラッド鋼の 腐食試験結果例（圧延クラッド鋼）

\begin{tabular}{|c|c|c|c|c|c|c|c|}
\hline \multicolumn{2}{|l|}{ 句 } & \multicolumn{2}{|c|}{$\begin{array}{l}\text { 全面腐食 } \\
\left.5 \% \mathrm{H}_{2} \mathrm{SO}_{4}{ }^{1}\right) \\
\left(\mathrm{g} / \mathrm{m}^{2} \cdot \mathrm{h}\right)\end{array}$} & \multicolumn{2}{|c|}{$\begin{array}{l}\text { 粒界腐食 } \\
\left.\mathrm{H}_{2} \mathrm{SO}_{4}-{ }^{2}\right) \\
(\mathrm{mm} / \text { year })\end{array}$} & \multicolumn{2}{|c|}{$\begin{array}{c}\text { 孔 食 } \\
3 \% \mathrm{FeCl}_{3} \\
\left(\mathrm{~g} / \mathrm{m}^{2} \cdot \mathrm{h}\right)\end{array}$} \\
\hline \multirow{2}{*}{ TP $316 \mathrm{~L}$} & 合せ材 & 4.60 & 5.31 & 0.85 & 1.05 & 6.32 & 6.47 \\
\hline & 合せ材継手 & 5.40 & & & & 7.00 & \\
\hline \multirow{2}{*}{ P 329} & 合せ材 & 2.90 & 2.92 & & & 4.35 & 5.11 \\
\hline & 合せ材繳 & 1.60 & 1.71 & & & 3.58 & 3.96 \\
\hline \multirow{2}{*}{ ТР 444} & 合せ材 & & & 1.42 & 1.49 & 4.53 & 5.72 \\
\hline & 合せ材綪 & & & 0.85 & 0.88 & 6.04 & 7.76 \\
\hline \multirow{2}{*}{$\begin{array}{r}\text { インコロイ } \\
825\end{array}$} & 合せ材 & 0.50 & 0.54 & 0.22 & 0.23 & 2.19 & 2.48 \\
\hline & 合せ材継手 & 0.80 & 0.81 & 0.28 & 0.29 & 2.45 & 2.72 \\
\hline \multirow{2}{*}{$\begin{array}{r}\text { インコネル } \\
625\end{array}$} & 合せ材 & 0.50 & 0.51 & 0.29 & 0.29 & 0 & 0 \\
\hline & 合せ材継手 & 0.31 & 0.39 & 0.60 & 0.61 & 0 & 0 \\
\hline
\end{tabular}


表 10 各種圧延クラッド鋼の海水浸漬試験結果

（室欄港スプラッシュゾーン，1 年間）

\begin{tabular}{|c|c|c|c|c|c|c|c|}
\hline \multirow{2}{*}{ 材 } & \multirow{2}{*}{ 料 } & \multicolumn{2}{|c|}{ 腐 食 减 量 } & \multicolumn{2}{|c|}{ 腐 } & \multicolumn{2}{|l|}{ 況 } \\
\hline & & $\mathrm{mg} / \mathrm{cm}^{2}$ & $\mathrm{~mm} /$ year & スキマ腐食 & 孔食 & フジッボ腐食 & 全面腐食 \\
\hline \multirow{2}{*}{ TP 304} & 単 体 & 3.52 & 0.00 & $\triangle$ & $x$ & $x$ & 0 \\
\hline & クラッド継手 & 3.84 & 0.01 & $\triangle$ & $x$ & $x$ & 0 \\
\hline \multirow{2}{*}{ TP 316} & 単 体 & 0.24 & 0.00 & $\triangle$ & $\mathrm{O}$ & $x$ & $\mathrm{O}$ \\
\hline & クラッド継手 & 0.27 & 0.00 & $\triangle$ & 0 & $x$ & 0 \\
\hline \multirow{2}{*}{ TP 329} & 単 体 & 1.20 & 0.00 & 0 & 0 & $x$ & $\mathrm{O}$ \\
\hline & クラッド継手 & 0.64 & 0.00 & 0 & 0 & $x$ & $\mathrm{O}$ \\
\hline \multirow{2}{*}{ ネーバル黄銅 } & 単 体 & 18.8 & 0.02 & $\triangle$ & - & $x$ & $x$ \\
\hline & クラッド継手 & 18.9 & 0.02 & $\triangle$ & - & $x$ & $x$ \\
\hline \multirow{2}{*}{ アルミ青銅 } & 単 体 & 12.0 & 0.02 & $\triangle$ & - & $x$ & $x$ \\
\hline & クラッド継手 & 19.5 & 0.02 & $\triangle$ & - & $x$ & $x$ \\
\hline \multicolumn{2}{|c|}{ SB 46} & 101 & 0.13 & $x$ & - & $x$ & $x$ \\
\hline
\end{tabular}

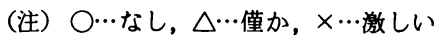

表 11 圧延 $90 / 10$ キュプロニッケルクラッド鋼の 腐食試験結果

\begin{tabular}{|c|c|c|c|}
\hline \multirow[b]{2}{*}{ 材 } & \multicolumn{3}{|c|}{ 腐 食 度, $\mathrm{mg} / \mathrm{cm}^{2}(\mathrm{~mm} /$ year $)$} \\
\hline & \begin{tabular}{|c|} 
人工海水浸漬試験 \\
$80 \mathrm{C}, 20$ 日 $^{1)}$ \\
\end{tabular} & 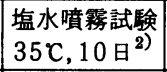 & \begin{tabular}{|l} 
回転円板試験 \\
$54 \mathrm{C}, 6$ 日 $^{3)}$ \\
\end{tabular} \\
\hline 体 & $\begin{array}{cl}3.4, & 3.7 \\
(0.07, & 0.08)\end{array}$ & $\begin{array}{c}0.9,1.0 \\
(0.04,0.04)\end{array}$ & $\begin{array}{c}1.3,1.5 \\
(0.09,0.10)\end{array}$ \\
\hline クラッド & $\begin{aligned} & 3.3, 3.6 \\
&(0.07,0.07) \\
&\end{aligned}$ & $\begin{array}{c}1.2,1.2 \\
(0.05,0.05)\end{array}$ & $\begin{array}{c}1.4,1.5 \\
(0.10,0.10) \\
\end{array}$ \\
\hline $\begin{array}{l}\text { クラッド継手 } \\
-1^{4)}\end{array}$ & $\begin{aligned} & 3.0, 3.5 \\
&(0.06,0.07) \\
&\end{aligned}$ & $\begin{array}{c}0.9,1.1 \\
(0.04,0.05) \\
\end{array}$ & $\begin{array}{c}1.2,1.2 \\
(0.08,0.08) \\
\end{array}$ \\
\hline $\begin{array}{l}\text { クラッド継手 } \\
-2^{4)}\end{array}$ & $\begin{aligned} & 3.5, 3.5 \\
&(0.07,0.07) \\
&\end{aligned}$ & $\begin{array}{c}1.1,1.2 \\
(0.05,0.05)\end{array}$ & $\begin{array}{c}1.3,1.3 \\
(0.09,0.09) \\
\end{array}$ \\
\hline $\begin{array}{l}\text { 1) 人工海刀 } \\
\text { 2) ASTM } \\
\text { 8) 自然海 } \\
\text { 4) }\end{array}$ & $\begin{array}{l}\text { ASTM D } 11 \\
117 \\
\text { 流速 : } 2.0 \sim 2 . \\
\text { ヒネル } 90 / 1\end{array}$ & 30 & \\
\hline
\end{tabular}

表 12 クラッド鋼の標準ガス切断条件

\begin{tabular}{|c|c|c|c|c|c|c|}
\hline \multirow{2}{*}{$\begin{array}{l}\text { 板厚 } \\
(\mathrm{mm})\end{array}$} & \multicolumn{2}{|c|}{$\begin{array}{c}\text { 火 } \mathrm{a} \text { 径 } \\
(\mathrm{mm})\end{array}$} & \multicolumn{2}{|c|}{$\begin{array}{l}\text { 酸 素 圧 } \\
\left(\mathrm{kg} / \mathrm{cm}^{2}\right)\end{array}$} & \multicolumn{2}{|c|}{$\begin{array}{c}\text { 切 断 速 度 } \\
(\mathrm{mm} / \mathrm{min})\end{array}$} \\
\hline & クラッド鎆 & 軟鋼 & クラッド鋼 & 軟鋼 & クラッド鋼 & 軟鋼 \\
\hline 10 & 1.6 & 1.2 & 1.0 & 2.3 & $440 \sim 510$ & 480 \\
\hline 12 & 1.6 & 1.2 & 1.0 & 2.4 & $420 \sim 480$ & 460 \\
\hline 16 & 2.1 & 1.2 & 1.5 & 2.5 & $360 \sim 400$ & 430 \\
\hline 25 & 2.1 & 1.4 & 1.5 & 3.0 & 320 & 370 \\
\hline 50 & 2.4 & 1.8 & 2.0 & 3.0 & 240 & 280 \\
\hline
\end{tabular}

（注）酸素ーアセチレン炎，クラッド母材：軟鋼

防ぐため合せ材表面を傷つけないよう注意が必要である （1）冷間加工 クラッド鋼の加工は，合せ材の耐食 性の観点から冷間で行われるのが好ましいが, 冷間加工 によって大きな加工度を与える場合には延じん性の優れ た母材を使用するととが必要である．合せ材の種類およ びそのクラッド比によってスプリングバック量は変化し，
加工に要する荷重も変化するので注意が必要であるとと あに，ポリエチレンシートやゴムなどで冶具あるいは合 せ材面を被覆して合せ材を傷つけない配慮が必要である. また，合せ材に付着した油類は，ステンレスクラッド鋼 やニッケル合金クラッド鋼では，溶接あるいは熱処理時 浸炭の原因となるので十分これを除去してやる必要があ る.

（2）熱間加工 熱間加工を行う場合，ステンレス鋼 のようにある温度域で鋭敏化が問題となるもの, キュプ ロニッケルのように中間温度脆性を示すむの, 加熱雾囲 気により酸化, 浸炭あるいはサルファーアタックを受け るものと様 々であり, 合せ材の特性を良く理解し, 適正 な加熱雾囲気や加工温度を選択しなければならない.

5.3 溶 接 クラッド鋼の溶接においては, 母材 強度の確保之同時に合せ材と同等かそれ以上の耐食耐久 性の確保が必要である．合せ材の溶接は，母材を溶接し た後行うのが原則であり，乙の場合接合界面で必然的に 異材溶接となる. このため溶接材料の選定, 開先形状, 溶接条件および後熱処理などに十分な注意が必要よなる。

母材溶接として被覆アーク溶接, サブマージアーク溶 接, 炭酸ガスアーク溶接, ティグ溶接, ミグ溶接, セル フシールドアーク溶接などが用いられ，合せ材溶接とし てはその外にプラズマアーク溶接などが用いられている.

（1）開先加工 図6にクラッド鋼の溶接に用いられ る代表的な開先形状を示した。母材の溶接においては, 合せ材を溶け込ませないてとが重要である.そのために は開先は精度よく仕上げることが必要であり，加工は機 械加工によることが望ましい. ガス切断あるいはプラズ マ切断による場合には、グラインダーなどによりスケー ルや異物を十分に除去する必要がある. 図 7 に付属品取 付け溶接継手の例を示した。

（2）溶 接 クラッド鋼の溶接は，まず母材を溶接 した後合せ材の溶接を行うのが普通であり，ての場合の 標準的な溶接手順を図 8 に示した。 母材の溶接では溶接 


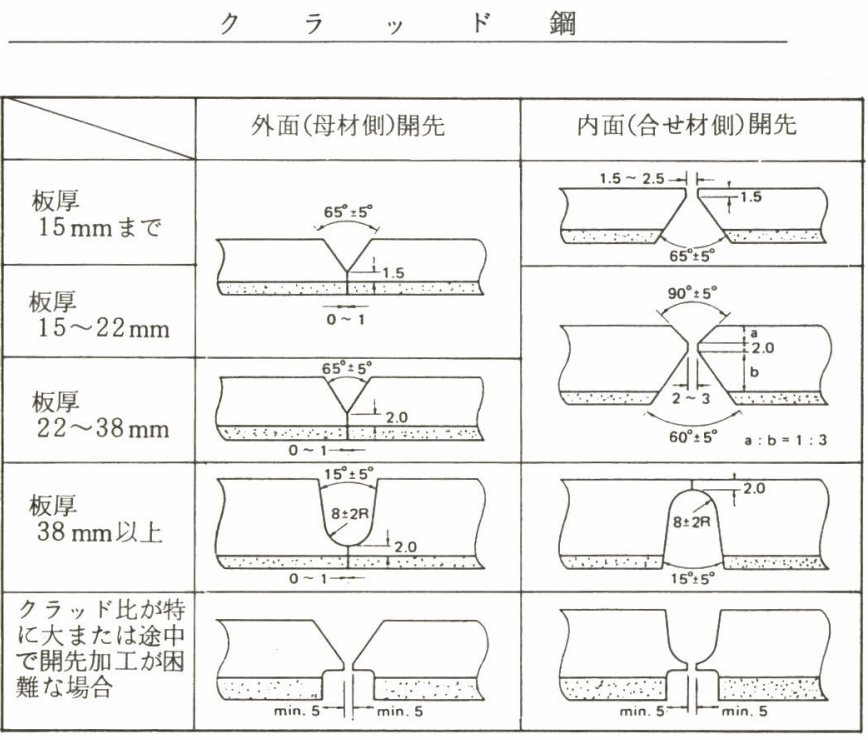

図6 クラッド鋼の溶接に用いられる代表的な開先形状

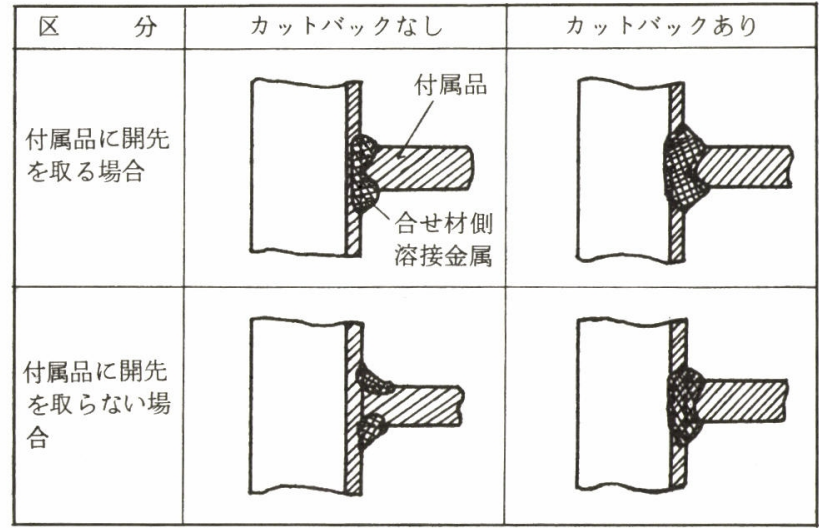

1）合せ材にステンレス鋼付属品が溶接される場合

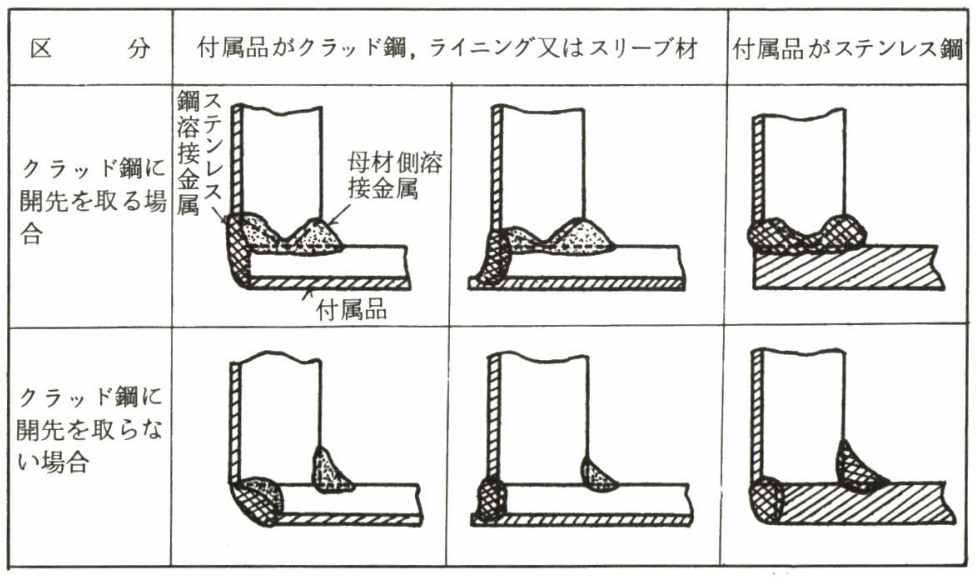

2）クラッド鋼を貫通して付属品が取付け溶接される場合

図 7 付属品取付け溶接継手の例 


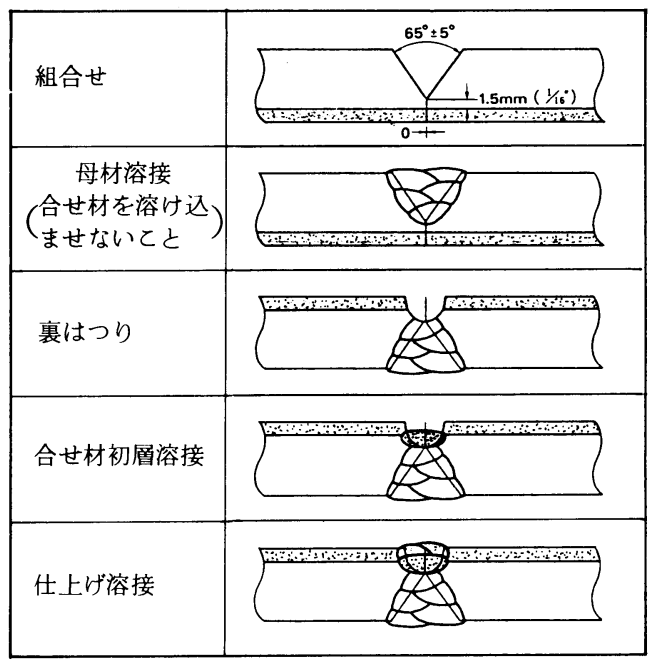

困 8 クラッド鋼の標準的な積層手順

金属の硬化，割れを起こさないために，合せ材を溶かし 込ませないようにする。

合せ材の溶接においては溶接割れの防止ならびに耐食 性の確保が最む重要である. 銅合金, ニッケル合金は高 温割れを起としやすいため, 予熱, パス間温度および溶 接入熱を制限する必要がある. 銅 ー ニッケル合金は図 9 に示すよう に鉄の希棌により高温割れ感受性 を増すため, キュプロニッケルク ラッド鋼の合せ材初層溶接では, 鉄の希釈の少ない溶接法を採用す るとともに，鉄の固溶量の大きな モネルやニッケルを下盛すると良 い.

合せ材溶接金属は鉄の希釈によ り合金成分が低下し耐食性が劣化 するため, 鉄の希釈を見込んで溶 接方法を選定する必要がある. 表 13 はクラッド鋼の溶接に用いら れる溶接材料の組合せ例を示した あのである・ステンレス鋼などの ように鉄をべースとした合せ材で は, 合せ材より高い合金成分の溶 接材料を使用することにより一層 盛でも良好な耐食性を得ることが できるが，ほとんどの銅合金およ びニッケル合金では溶接金属中の 鉄量が規定されるため, 希釈率の 小さい溶接を行うとともに二層あ るいは三層盛以上の溶接が必要と なる. 表 14 にインコネル625ク ラッド鋼および $90 / 10$ キュプロニ

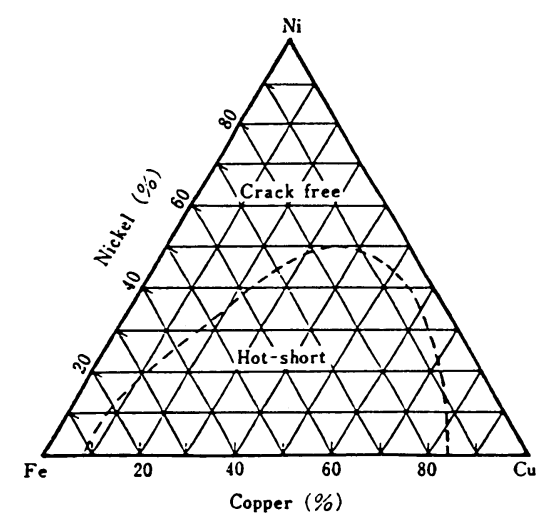

図 $9 \mathrm{Cu}-\mathrm{Ni}-\mathrm{Fe}$ 合金の高温割れ感受性

ッケルクラッド鋼三層盛の場合の鉄量変化を示した ${ }^{12)}$.

予熱は母材の材質, 板厚に応じて行えば良いが, 合せ 材の溶接においては高温割れの見地からはむしろ好まし くない場合が多い，溶接後熱処理は，オーステナイト系 ステンレス鋼やニッケル合金を合せ材とするクラッド鋼 の場合鋭敏化などむしろマイナス面が大きい。したがっ て，母材に対して溶接後熱処理が要求される場合，低炭 素タイプあるいは $\mathrm{Nb}, \mathrm{Ti}$ などで炭素を固定した合せ材

表 13 クラッド鋼に用いられる溶接材料例

\begin{tabular}{|c|c|c|c|}
\hline \multicolumn{2}{|c|}{ クラッド鋼の種類 } & \multicolumn{2}{|c|}{ 使 用 溶 接 棒 } \\
\hline \multirow{6}{*}{$\begin{array}{l}\text { ステンレス } \\
\text { クラッド鋼 }\end{array}$} & 合 せ 材 & 初 & 2 層目以降 \\
\hline & $304,304 \mathrm{~L}$ & $309,309 \mathrm{~L}$ & $308,308 \mathrm{~L}$ \\
\hline & $316,316 \mathrm{~L}$ & $309,309 \mathrm{~L}, 309 \mathrm{Mo}$ & $316,316 \mathrm{~L}$ \\
\hline & 347,321 & $309,309 \mathrm{~L}, 309 \mathrm{cb}$ & 347 \\
\hline & 329 & $309 \mathrm{Mo}$ & 329 \\
\hline & 405 & $430(\mathrm{cb})$ & $410(\mathrm{cb})$ \\
\hline \multirow{4}{*}{$\begin{array}{lll}\text { 銅 } & \text { 合 } & \text { 金 } \\
\text { クラッド鋼 }\end{array}$} & 銅 & 銅, モネル，キュプロニッケル & 銅 \\
\hline & キュプロニッケル & $\begin{array}{l}\text { キュプロニッケル, モネル, } \\
\text { ニッケル }\end{array}$ & キュプロニッケル \\
\hline & アルミ青 銅 & 青 銅 & アルミ青銅 \\
\hline & ネーバル黄銅 & アル ミ 青 銅 & アルミ青 銅 \\
\hline \multirow{3}{*}{$\begin{array}{l}\text { ニッケル合金 } \\
\text { クラッド鋼 }\end{array}$} & $\%$ ケ & ル & $\%$ \\
\hline & ル & モネル，ニッケル & ネ \\
\hline & インコネル & インコネル,ニッケル & ンコネル \\
\hline
\end{tabular}

表 14 インコネル 625 および $90 / 10$ キュプロニッケルクラッド鋼 合せ材溶接部の鉄量の変化

\begin{tabular}{|c|c|c|c|c|c|}
\hline \multirow{2}{*}{ クラッド鋼種 } & \multirow{2}{*}{ 溶接方法 } & \multirow{2}{*}{ 溶材 } & \multicolumn{3}{|c|}{ 鉄量 (\%) } \\
\hline & & & 一層目 & 二層目 & 三層目 \\
\hline インコネル 625 & SMAW & E $\mathrm{NiCrMo}-3$ & 22.7 & 10.3 & 6.8 \\
\hline \multirow{3}{*}{$90 / 10$ キュプロニッケル } & \multirow{3}{*}{ TIG } & $90 / 10 \mathrm{Cu}-\mathrm{Ni}$ & 7.1 & 1.9 & 1.1 \\
\hline & & $\begin{array}{l}\text { ER } \mathrm{NiCu}-7 \\
+90 / 10 \mathrm{Cu}-\mathrm{Ni}\end{array}$ & 20.1 & 7.2 & 1.8 \\
\hline & & $\begin{array}{l}\text { ER } \mathrm{Ni}-1 \\
+90 / 10 \mathrm{Cu}-\mathrm{Ni}\end{array}$ & 31.9 & 8.1 & 2.1 \\
\hline
\end{tabular}


を採用するなどの配慮が必要である.

クラッド鋼の両面より溶接が可能な場合には, 以上に 述べた点に注意して容易に良好な継手を得ることができ る. しかし, パイプなど肉側からの合せ材溶接が不可能 で母材側からの片面溶接とならざるを得ない場合がある. この場合には, 合せ材の裹波溶接を行った後, 合せ材の 種類, 母材の強度などによって, オーステナイト系ステ ンレス鋼,インコネルあるいはモネルなどによる溶接が 行われている.

\section{6. クラッド鋼の用途}

表 15 はクラッド鋼に用いられる主なステンレス鋼の 特徴とクラッド鋼としての用途を，表 16 はその分野別 の用途を示したあのである. 各種産業分野で広く使用さ れていることが分る.

非鉄クラッド鋼は造水工業, 海水熱交, 海洋構造物, 食品工業の外各種化学産業の装置に用いられてきている. この内, 現在最も大量に使用されているのがキュプロニ ッケルクラッド鋼であり主として淡水化装置用材料之し て用いられている外, 最近では省エネルギ船の建造にも 使用されてきている ${ }^{13)}$. 非鉄クラッド鋼ではての外ステ ンレスクラッド鋼では得られない高耐食性を有するもの が多く、今後海洋開発, 地熱開発などの分野において用 途が増していくものと思われる. また, 特殊な例として アルミクラッド鋼を, 融接不可能なアルミニウムと鋼のト ランジッションジョイントとして用いた例もある゙ ${ }^{3)}$.

\section{7.おわりに}

以上, 加工ならびに溶接などを含めクラッド鋼の概要
表 16 ステンレスクラッド鋼板の用途(分野別)

\begin{tabular}{|c|c|}
\hline & \\
\hline 这用 & バキュームタワー,コークドラム \\
\hline 2. 石油化学用 & リアクター, タワー, ベッセル，熱交等 \\
\hline 学用 & 合成繊維製造装置用ベッセル等 \\
\hline & 製紙機械用ダイジェスター等 \\
\hline & 造水装置用エバポレーター, 熱交等 \\
\hline & 人造結晶合成用オートクレーブ等 \\
\hline & 苛性ソーダ製造装置用エバポレーター等 \\
\hline & 製塩装置用エバポレーター等 \\
\hline & $\begin{array}{l}\text { 肥料製造装置用リアクター, タワー, } \\
\text { セル等 }\end{array}$ \\
\hline 4. 産業機械用 & $\begin{array}{l}\text { ダムゲート, 放水管, 温水ボイラー等 } \\
\text { 排煙脱硫用吸収搭, 酸化搭等 }\end{array}$ \\
\hline & 排水排液処理用リアクター等 \\
\hline & タンク車用タンク等 \\
\hline 5. 薬 & 消毒殺菌用機器等 \\
\hline 5. 食品, 醸造用 & 眝蔵用タンク, 摚拌槽等 \\
\hline 船 用 & $\begin{array}{l}\text { プロペラノズル，ケミカルタンカー用タ } \\
\text { ク等 }\end{array}$ \\
\hline 子力用 & 加厈器，脱塩装置，純水装置等 \\
\hline
\end{tabular}

を述べてきた. 各種耐食材料を効率的に使用する方法之 して, クラッド鋼は非常に有効な手段であり, 現在以上 に各分野へ適用されていくものと思われる. しかしなが ら,クラッド鋼の使用性能などに関するデータはまだま だ不足しているのが事実で, 今後てれらデータの収集を 続けていく必要がある.

\section{文献}

1）日本高压力技術協会講習会資料「エネルギ問題におりる クラッド鋼と複合材料の適用に関する最近の進歩」, 1980 年 12 月.

2）池貝ほか, 高圧力, Vol.8, No. 5, p. 2096 (1970).

表 15 クラッド鋼に用いられる主なステンレス鋼の発展経過とクラッド鋼としての主な用途

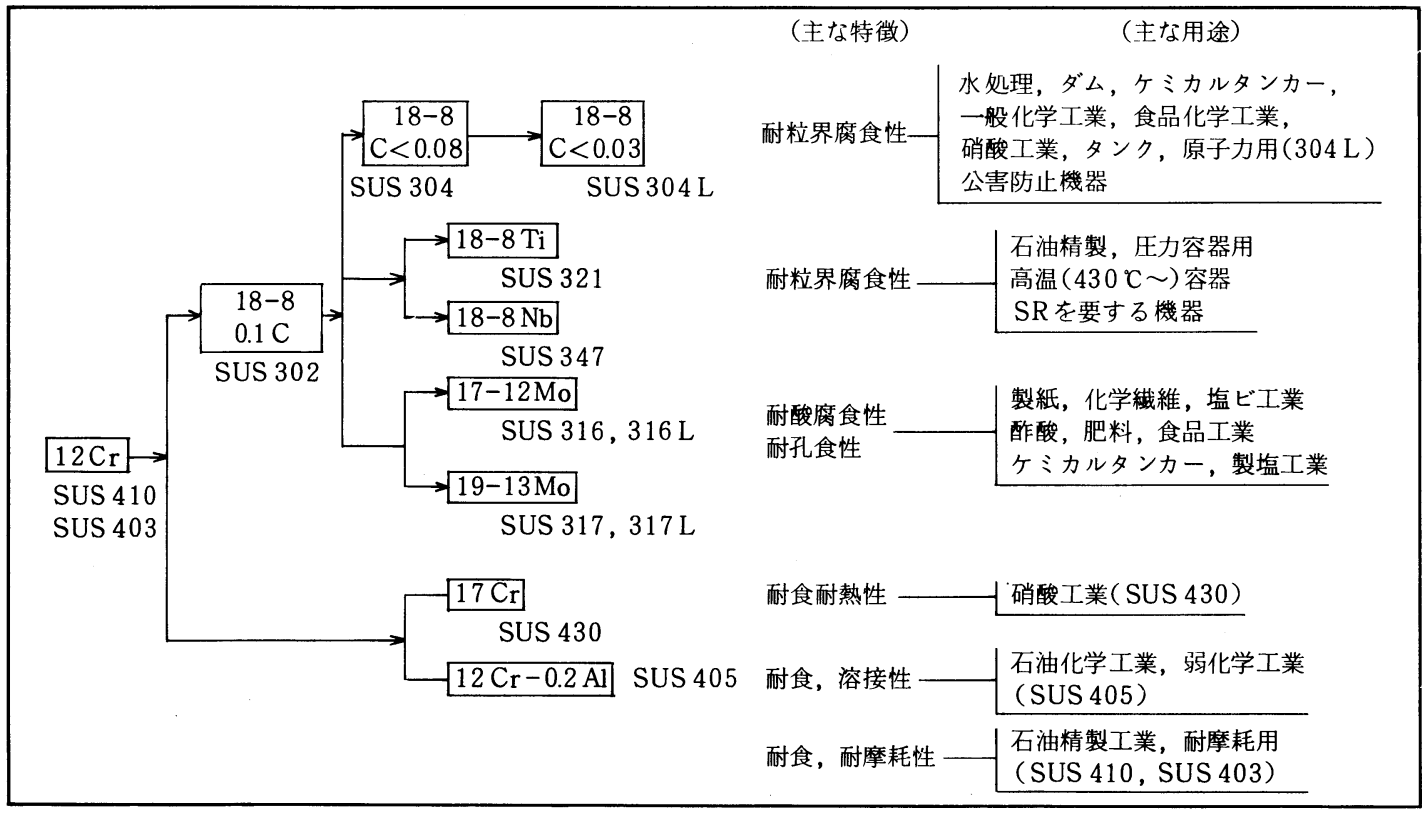


3) 福山, 高圧力, Vol. 8, No. 5, p. 2114 (1970).

4) 稲垣, 高圧力, Vol. 8, No. 5, p. 2102 (1970).

5) 山路, 金属材料, Vol. 9, No. 11, p. 98 (1969).

6）稲垣ほ力, 圧力技術, Vol. 15, No. 1, p. 2(1977).

7）進藤ほか，日本製鋼所技報，Vol. 36，p. 1 (1975).

8) L. Egnell et al., Instn. Mech. Engineers, Conference
Publication, 13 (1973).

9）日本製鋼所，研究室報告, PL 73-3-448.

10）日本製鋼所，研究報告，第 51-14 号など.

11）山崎ほか, 金属材料, Vol. 15, No.8, p. 64 (1975).

12）日本製鋼所, 研究室報告, R (PL ) 81-061など.

13) M. Prager, Welding J., Vol. 59, No. 7, p. 17(1979).

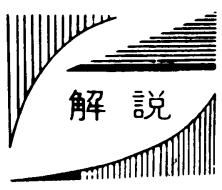

耐 食 鋼 材

\section{1. 緒言}

最近の各種工業の著しい発展に伴い, 使用環境が厳し くなるとともに，より経済的な耐食鋼が要求されるよう になってきた。

特にボイラに扔いても燃料中の硫黄に起因する腐食が 多く発生しているが, その節炭器または空気予熱器など の低温部においては，燃料中の硫黄による露点腐食が大 きな問題となっている. また, ボイラ以外には公㲅防止 機器など諸排気ガスの処理設備においてあての種の低温 腐食が問題になる。そてで，乙の種の用途に使用するに 適した鋼材として，当社で開発された耐食鋼材 NAC-1 およびNAC-2 の諸性質ならびに，耐食性鋼材の最近の 動向を述べ，耐食鋼材の実際を知って頂くことにする.

\section{2. 耐食鋼材の最近の技術}

各種使用環境下における鋼の腐食に関して，かなりの 研究が進んでおり，現在では，使用環境，目的に応じた 各種の耐食鋼材が開発されている，すなわち，橋りょう など，大気中の耐食性に優れた耐候性鋼，海洋構造物な どに有利な耐海水鋼, 化学プラント類への耐応力腐食割 れ鋼，耐硫酸鋼，工業用水や上水などの配管に使用する 耐溝状腐食電縫鋼管，サワーガス用パイプラインに使用 される耐水素誘起割れ鋼材などがある.

いずれす，各種環境下での耐食性を向上させる方法と して，微量の合金元素を添加したり，耐食性に有害とさ れる鋼中の Sなどの不純物元素を低減させている。ここ では，後述する耐硫酸鋼以外の耐食鋼材のうち，最近の 動向のいくつかの例について紹介する.

2.1 耐候性鋼 耐候性鋼材とは，大気中の耐食性 が普通鋼より優れ，しかも，溶接性，加工性に扑いても 普通鋼と同等の低合金鋼である．添加元素として Cu，

* 原稿受付 昭和 56 年 11 月 18 日

** 日本鋼管 (株) 鉄鋼技術部(東京都千代田区丸の内 1-1-2)

\section{山口哲夫 ${ }^{* *}$. 村瀬貞彦 ${ }^{* *}$}

$\mathrm{Cr} ， \mathrm{Mo}, \mathrm{Ni} ， \mathrm{~V}$ などを適量加え，大気中に放置した場 合，表面に硬くて維密な酸化被膜を形成させることで大 気中の耐食性を向上させている.

従来，耐候性鋼は，防錆之周辺の美観維持の観点から 塗装を行って使用されるのが一般的であり，無鈝装で使 用される例は日本ではそれほど多くなかった。しかし， 最近では，建設時の塗装費やメインテナンス費が不要と なる経済的有利さから，橋りょうを中心として無塗装で 使用される場合が増えている，乙の場合， $\mathrm{Cu}, \mathrm{Cr}$ の添 加量を増やすととが有効とされるので, 最近の動向を反 映してJISが改正されるととになっている.

2.2 耐応力府食ワレ鋼 化学プラントに使用さ れる鋼材は, 使用環境下に扑いて応力腐食ワレが発生す る場合がある．LPGや原油タンクでの硫化物応力腐食 ワレ, 肥料プラントでの硝酸塩系応力腐食ワレなどがあ る. 硫化水素応力腐食ワレについては Ni が添加された HT 80 に発生しやすいため, $\mathrm{Ni}$ の添加されていない $\mathrm{HT}$ 80 が開発されている．また，溶接部の熱影響部の硬度 が高いと割れが発生しやすいため，炭素当量を低減した 鋼材を使用し，溶接条件を適正化し，残留応力の除去な どの配慮を行っている.

2.3 耐水素誘起ワレ鋼 天然ガスや原油中の $\mathrm{H}_{2} \mathrm{~S}$ 濃度が高いと，解離した水素がパイプラインの鋼中 に浸入し，鋼内部にワレ，あるいは，表面にブリスター が発生する. 鋼中の硫化物系介在物がワレの起点になる ことから，対策として鋼中の S 極度に低下する方法が とられている. 最近の製鋼法の著しい進歩により， Sを $0.001 \%$ 以下に低下した鋼も開発されている.また， $\mathrm{Ca}$ やREM (希土類元素)を添加して, 有害な硫化物系介在 物の形状を球状化し，害を少なくする方法む開発されて いる.

\section{3. 耐食鋼材 NAC-1 およびNAC-2}

両鋼材は最近当社で開発されたものであって，硫酸あ 